\title{
Developmental trade-offs in Subantarctic meroplankton communities and the enigma of low decapod diversity in high southern latitudes
}

\author{
S. Thatje ${ }^{*}$, S. Schnack-Schiel, W. E. Arntz \\ Alfred Wegener Institute for Polar and Marine Research, PO Box 120 161, 27515 Bremerhaven, Germany
}

\begin{abstract}
Developmental modes, occurrence and distribution patterns of invertebrate larvae were studied in the Subantarctic Magellan region of South America on the basis of quantitative plankton hauls obtained during the 'Victor Hensen' campaign in November 1994. The meroplankton community was found to be numerically dominated by decapod crustacean larvae $(47 \%)$, followed by polychaetes $(20 \%)$, echinoderms $(16 \%)$, cirripedes $(8 \%)$ and molluscs $(7 \%)$. A rich decapod community was detected, with 2 thalassinid, 5 brachyuran, 4 anomuran, 6 caridean, 1 astacid and 1 palinurid species/morphotypes identified. Cluster analyses clearly distinguished deep-water stations (250 to $400 \mathrm{~m}$ ) south of the Straits of Magellan from shallow-water stations (30 to $100 \mathrm{~m}$ ) in the Beagle Channel, where meroplankton was dominated by decapod larvae $(>90 \%)$. Three main larval developmental modes, characterised by morphogenesis, mode of larval nutrition and site of larval development, were observed in Magellan decapods: (1) Extended, planktotrophic development of planktonic larvae; (2) abbreviated, planktotrophic development of planktonic larvae; and (3) abbreviated, endotrophic (lecithotrophic) development of demersally living larvae. Several caridean shrimps with abbreviated larval development, which have congeners in the Antarctic, suggest a strong synchronisation between abbreviated planktotrophic larval development and short periods of primary production. This seems to be an essential factor in early life history adaptation for the colonisation of the Antarctic environment. The impoverished Antarctic decapod fauna, with only a few representatives of caridean shrimp species left, may be related to the lack in flexibility of reptant decapods in distributing energy resources between adults and their offspring, which would allow abbreviated planktotrophic larval development.
\end{abstract}

KEY WORDS: Decapoda - Reproductive strategies - Southern Ocean - Abbreviated larval development $\cdot$ Magellan region $\cdot$ Antarctic

Resale or republication not permitted without written consent of the publisher

\section{INTRODUCTION}

The Southern Ocean decapod fauna still provides one of the most conspicuous unsolved mysteries in marine biodiversity research, with an Antarctic decapod fauna of only about a dozen caridean shrimp representatives compared with more than 120 benthic and pelagic decapod species in the circumpolar antiboreal environment north of the Antarctic Convergence (Gorny 1999). Apart from a few species of lithodid crabs in the deeper waters off the Antarctic continental shelf (Macpherson
1988, Klages et al. 1995, Arana \& Retamal 2000), caridean shrimps represent the only decapod infraorder which endures the high Antarctic regime of very low temperatures combined with a marked seasonality of primary production (Clarke 1988).

The absence of reptant decapods, in particular brachyuran crabs, from polar environments of both hemispheres was recently discussed to be predominantly due to physiological constraints, i.e. the failure of adults to control high $\mathrm{Mg}^{2+}$ concentrations in their haemolymph, which in combination with low tempera- 
tures, leads to a paralysing condition affecting all kinds of behaviour (Frederich et al. 2001). However, this explanation of physiological constraints on ecological demands alone cannot explain the observed decapod biodiversity patterns, since at least lithodid (anomuran) crabs have been shown to respond to physiological constraints in the cold by life history adaptation of both adults and larvae (see Anger et al. 2003, Lovrich et al. 2003, Thatje et al. 2003). In an attempt to elucidate the reason for the impoverished decapod fauna in high latitudes, we revisited Thorson's old ecological concept (Thorson 1936, 1950), which, in summary, argues that the mismatch between a marked seasonality of primary production (i.e. food availability) and prolonged larval developmental times due to low temperatures at high latitudes, should strongly select against planktotrophic larval development (see Mileikowsky 1971, who created the term 'Thorson's rule', Clarke 1988, Pearse et al. 1991, Arntz \& Gili 2001).

In this study, we present information on developmental trade-offs in early life history of benthic decapod crustaceans from the Magellan region and the position of decapod larvae within the Subantarctic meroplankton community. This information is augmented by literature data, including findings on early life history adaptation of Antarctic shrimps to a cold and seasonally food-limited environment.

\section{MATERIALS AND METHODS}

Sampling and sample treatment. Quantitative meroplankton samples were obtained during the Joint Chilean-German-Italian Magellan 'Victor Hensen' Campaign to the channel and fjord system of the cold-temperate Subantarctic Magellan region (Fig. 1) from 12 to 24 November 1994 (see also Arntz \& Gorny 1996, DefrenJansen et al. 1999). Zooplankton samples were obtained using a multiple openingclosing net of $300 \mu \mathrm{m}$ mesh size. Daytime vertical hauls were conducted from the seafloor or $400 \mathrm{~m}$ maximum wire length to the surface, covering standard depth intervals (see Figs. 6 \& 7). Zooplankton samples were directly preserved in $4 \%$ boraxbuffered formaldehyde seawater solution, and later in the laboratory split into two. Assuming $100 \%$ filtering efficiency of the multinet for meroplankton, the filtered volume was calculated by multiplying the vertical distance of the tow by the mouth area of the net $\left(0.25 \mathrm{~m}^{2}\right)$.

Species identification and larval developmental mode. The meroplankton frac- tion was sorted only from one part of the sample, and identified to the most resolved taxonomic level possible. Special focus was given to species determination of decapod crustacean larvae as well as their developmental stages (for literature used for larval identification see Table 2). To detect relevant developmental patterns in decapod larvae, we distinguished 3 larval developmental modes, characterised as follows (for review see Williamson 1982, Anger 2001):

(1) Morphogenesis

- Extended larval development-number of instars typical of the family/genus.

- Abbreviated larval development - comprises a considerable reduction in larval instars compared with typical trait of family/genus representatives from lower latitudes and/or intraspecific changes with latitude/temperature regime.

(2) Mode of larval nutrition

- Planktotrophic larval development-most of the larval development requires actively feeding planktonic larvae. This may include partial utilisation of energy reserves of maternal origin in an early stage of development.

- Lecithotrophic larval development - complete endotrophic larval development (complete lecithotrophy) with planktonically and/or demersally living larvae.

(3) Site of larval development

- Planktonic larval development-larval development is spent mostly in the water column.

- Demersal larval development-larval development is predominantly epibenthic.

Cluster analyses. We used the software package PRIMER (Plymouth Routines in Multivariate Ecological Research) developed at Plymouth Marine Laboratory,

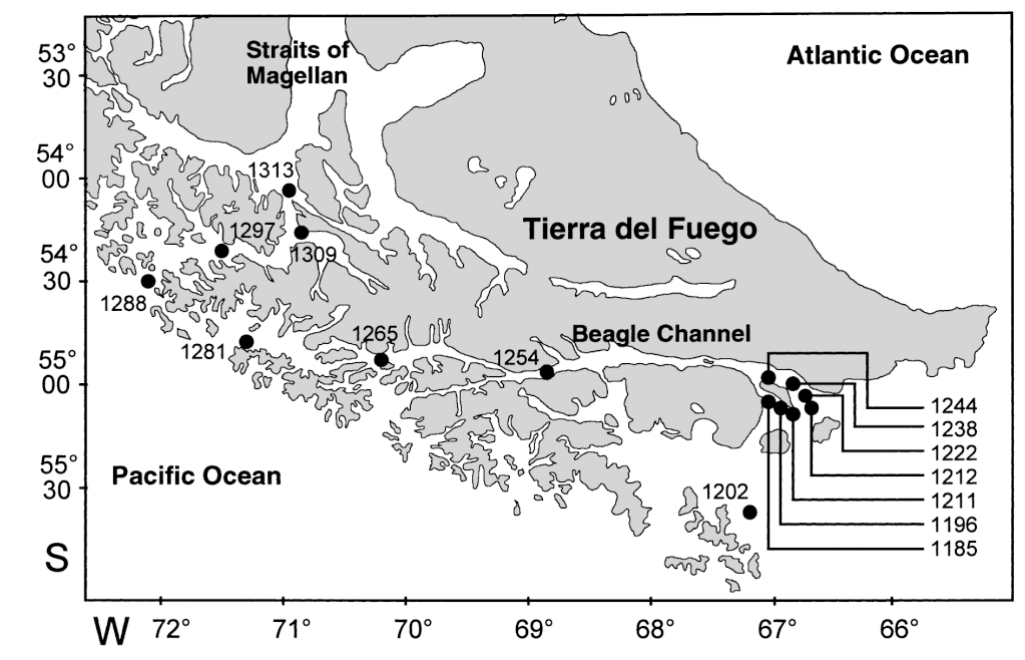

Fig. 1. Meroplankton sampling locations (black dots/station numbers) during the Joint Chilean-German-Italian Magellan 'Victor Hensen' Campaign to the Magellan region (South America) in November 1994 
Table 1. Station means (ind. $\mathrm{m}^{-3}$ ) of meroplankton taxa found in the channel and fjord system of the Subantarctic Magellan region during the Joint Chilean-German-Italian 'Victor Hensen' Campaign in November 1994 (adv. = advanced). (?) Species identification not certain

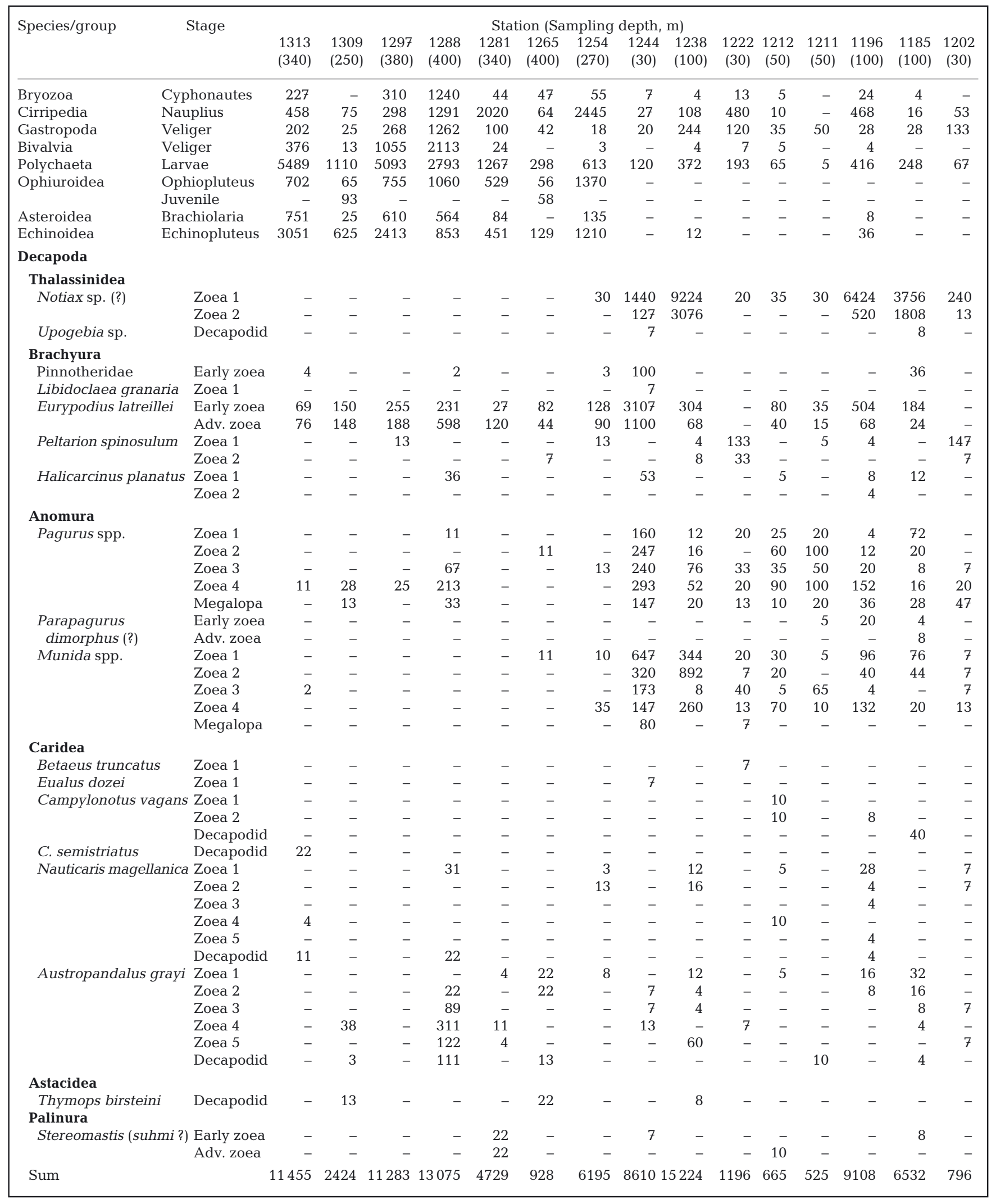


UK. The hierarchical agglomerate cluster method (Clarke \& Gorley 2001) was applied on the basis of abundance means per station to differentiate meroplankton communities utilising the Bray-Curtis similarity index. Data were previously $\log (x+1)$ transformed to remove the bias of highly abundant taxa.

\section{RESULTS}

\section{Meroplankton composition and distribution pattern}

The average spring meroplankton community found in the Magellan region is characterised by highly variable abundances (Table 1) and an overwhelming amount of crustaceans, namely decapod and cirripede larvae, contributing 47 and $8 \%$ to overall abundance means, respectively (Table 1, Fig. 2A). Polychaete

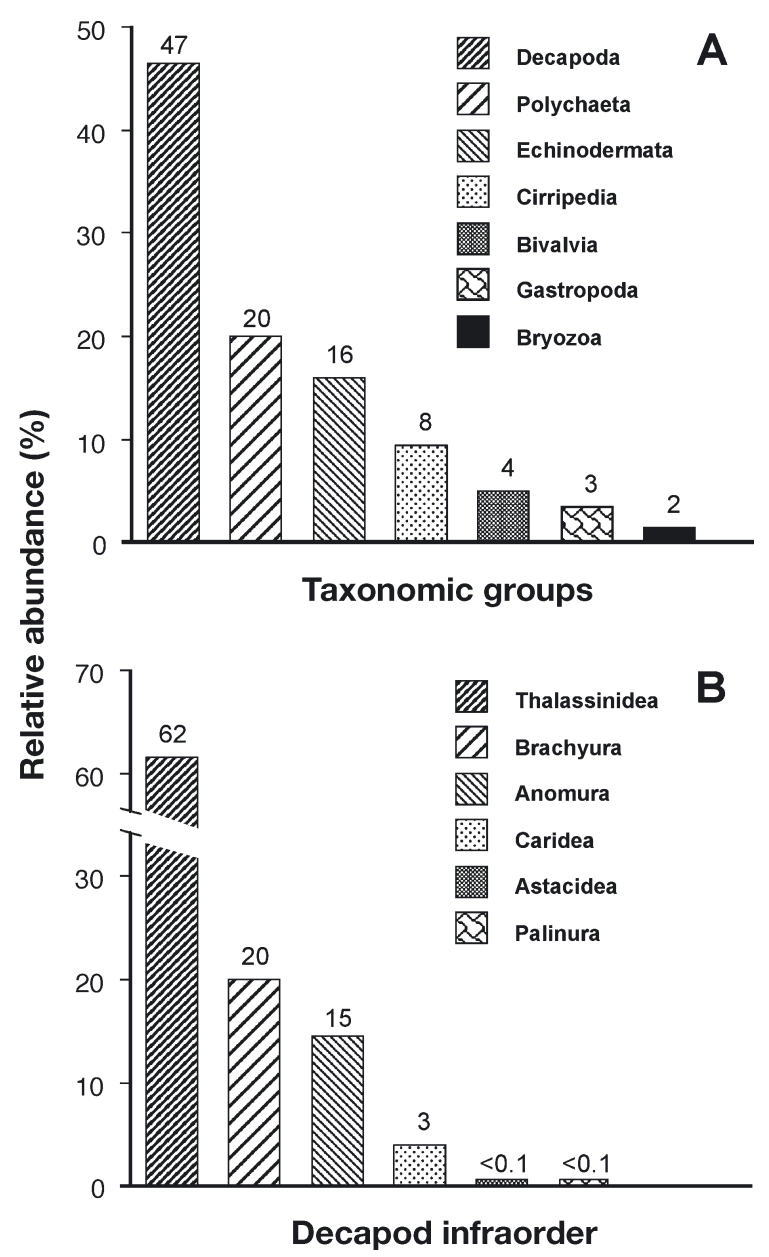

Fig. 2. Relative abundance of meroplankton fractions found in the channel and fjord system of the Magellan region in November 1994. Given on the basis of (A) major taxonomic groups and (B) decapod infraorder

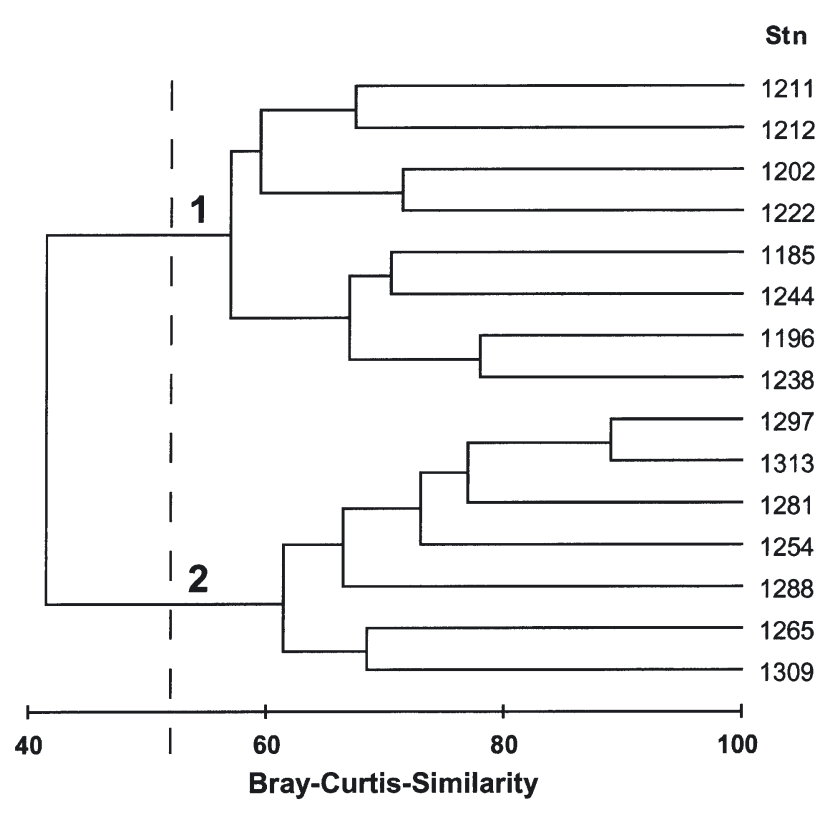

Fig. 3. Cluster dendrogramm (Bray-Curtis similarity) showing classification of meroplankton stations on the basis of abundance means

larvae ran second (20\%) followed by echinoderms $(16 \%)$; molluscs and bryozoans had much lower fractions (Fig. 2A). Within the decapod fraction, thalassinid larvae were found to be most abundant (62\%), followed by brachyurans (20\%) and anomurans (15\%) (Fig. 2B). Caridean shrimp larvae, Astacidea and Palinura were of minor importance (Fig 2B). Also, in terms of species/morphotype richness, decapods were the dominant group within the meroplankton, with 2 thalassinid, 1 astacid, 1 palinurid, 5 brachyuran, 4 anomuran and 6 caridean species distinguished (the 2 pagurid species Pagurus forceps and P. comptus are combined as Pagurus spp., due to the lack of knowledge of the complete larval development in $P$. forceps; S. Thatje \& G. Lovrich unpubl. data). Species determination of all other groups was complicated by the lack of adequate taxonomic keys, and therefore species richness must be considered as a minimum estimate on the basis of distinguished morphotypes: 3 bivalve, 2 gastropod, 2 to 4 ophiuroid, 1 echinoid, 1 cirripede and 1 bryozoan morphotypes were found. Polychaetes were more diverse, but remain to be further taxonomically identified. However, in relation to abundance, spionid larvae were the most dominant taxon (>60\%).

Cluster analyses of the meroplankton composition revealed 2 groupings at the $55 \%$ similarity level (Fig. 3). Group 1 comprises shallow-water stations with depths varying from 30 to $100 \mathrm{~m}$ (Table 1) at the eastern entrance of the Beagle Channel, including Stn 1202 off Isla Wollaston (Fig. 1, Stns 1185 to 1244). Group 2 com- 
bines 7 deep-water stations on a transect from the Straits of Magellan south to the Beagle Channel, with depths varying from 250 to $400 \mathrm{~m}$ (Figs. 1 \& 3, Table 1).

Shallow-water stations are overwhelmingly dominated by decapods (91\%, Fig. 4C) of which thalassinid larvae are most important (68\%, Fig. 4D), followed by brachyuran (16\%) and anomuran larvae (15\%). Polychaete, cirripede and gastropod larvae contribute with only 4, 3 and $2 \%$, respectively (Fig. 4C). Deep-water stations showed a more heterogeneous meroplankton composition (Fig. 4A), with polychaetes contributing $33 \%$, followed by echinoderms $(27 \%)$, cirripedes $(13 \%)$, decapods $(12 \%)$, bivalves $(7 \%)$, gastropods $(4 \%)$ and bryozoans ( $4 \%$ ). The generally less important decapod fraction is dominated by brachyuran crab larvae (61\%), carideans (24\%) and anomurans (12\%, Fig. 4B).

The meroplankton composition on a transect of deepwater station from the Straits of Magellan southward to the Beagle Channel differed totally from that of shallowwater stations (Figs. $1 \& 5$ ). Here, polychaetes and echi- noderms were the dominant taxa. Only Stns 1281 and 1254 showed a percentage of cirripede larvae untypical of deep-water stations, although they were very similar in their taxonomic composition, despite the lack of echinoderms, to Stn 1222 from the eastern entrance of the Beagle Channel. The numerical dominance of decapod larvae at the shallow-water stations is correlated with a mass-occurrence of thalassinid larvae at almost all stations (Fig. 5A,B). At shallow-water stations, in contrast to deep-water stations, anomuran larvae were proportionally dominant over brachyuran larvae (Fig. 5B).

\section{Vertical distribution of larvae}

At some stations with a strong thermocline, a concentration of meroplanktonic larvae was found (Stns 1254, 1281, 1288, Fig. 6). This holds true especially for cirripede nauplii and echinoderm larvae (Fig. 6), which were concentrated in the thermocline.

\section{Deep-water stations}

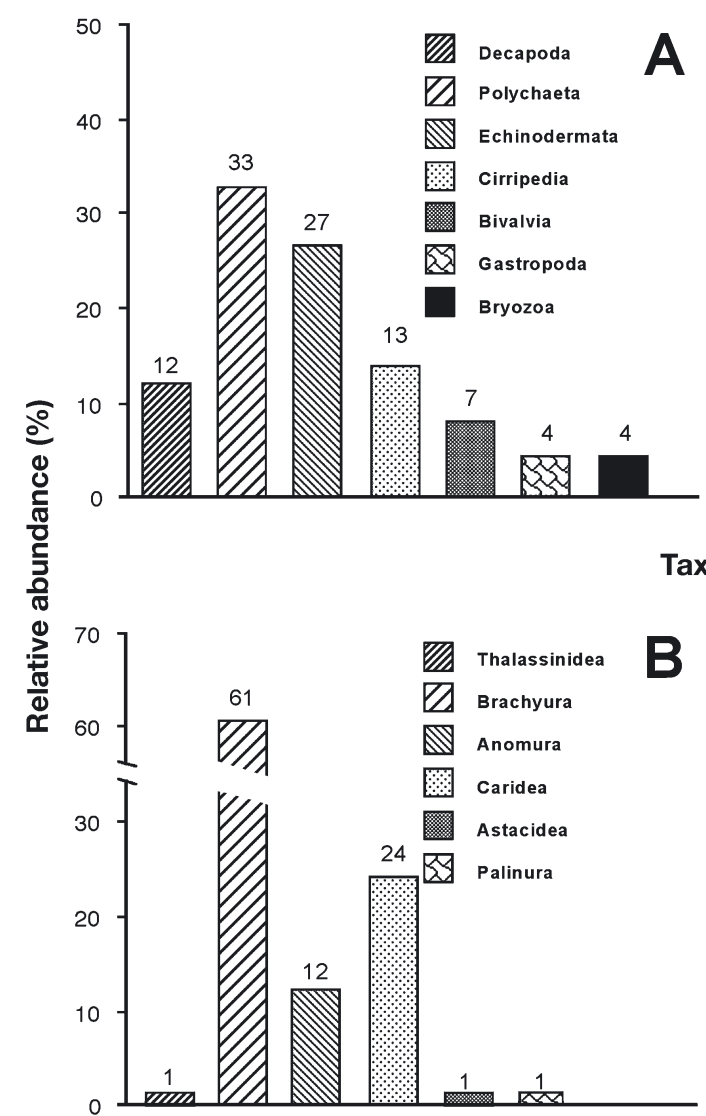

\section{Shallow-water stations}

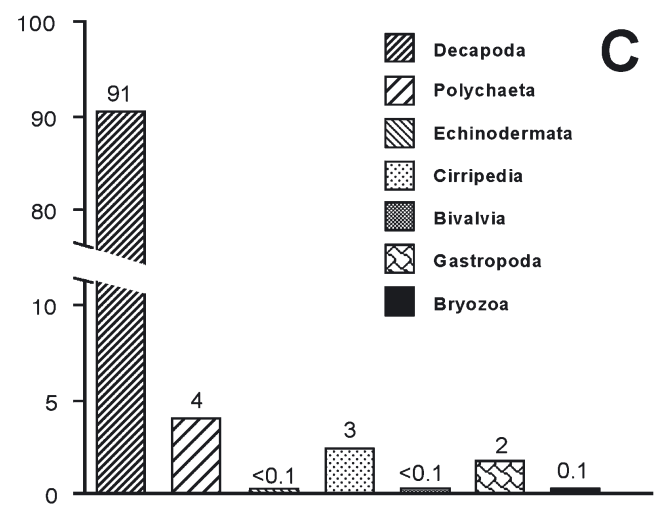

Taxonomic groups

\section{Decapod infraorder}

Fig. 4. Relative abundance of meroplankton fractions found in the channel and fjord system of the Magellan region in November 1994. Comparison of deep-water station means $(A, B)$ with that of shallow-water stations. Given on the basis of $(A, C)$ major taxonomic groups, (B,D) decapod infraorder 


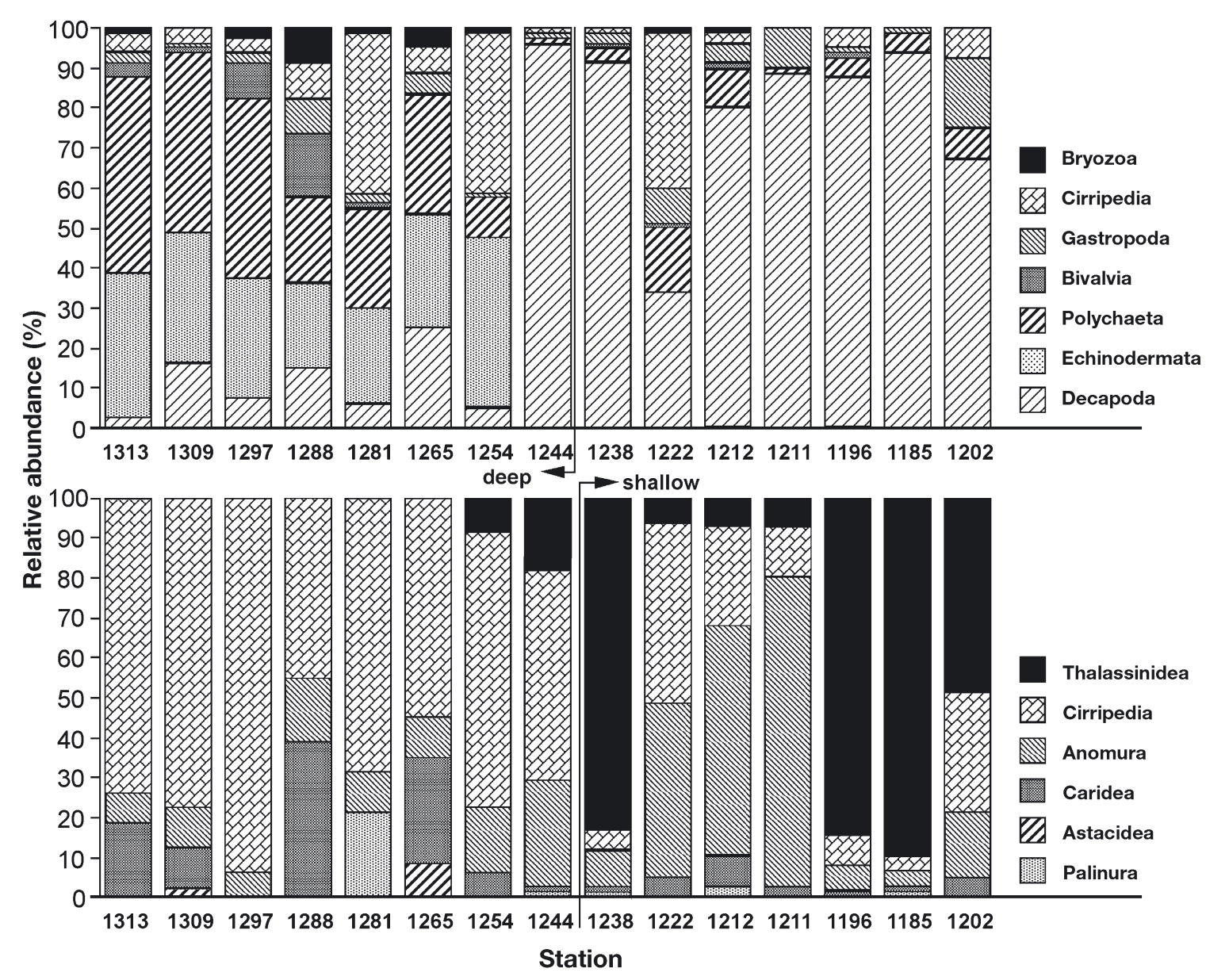

Fig. 5. Relative abundance of meroplankton fractions found at each station sampled in the Magellan region in November 1994. Given on the basis of (A) major taxonomic groups, (B) decapod infraorder
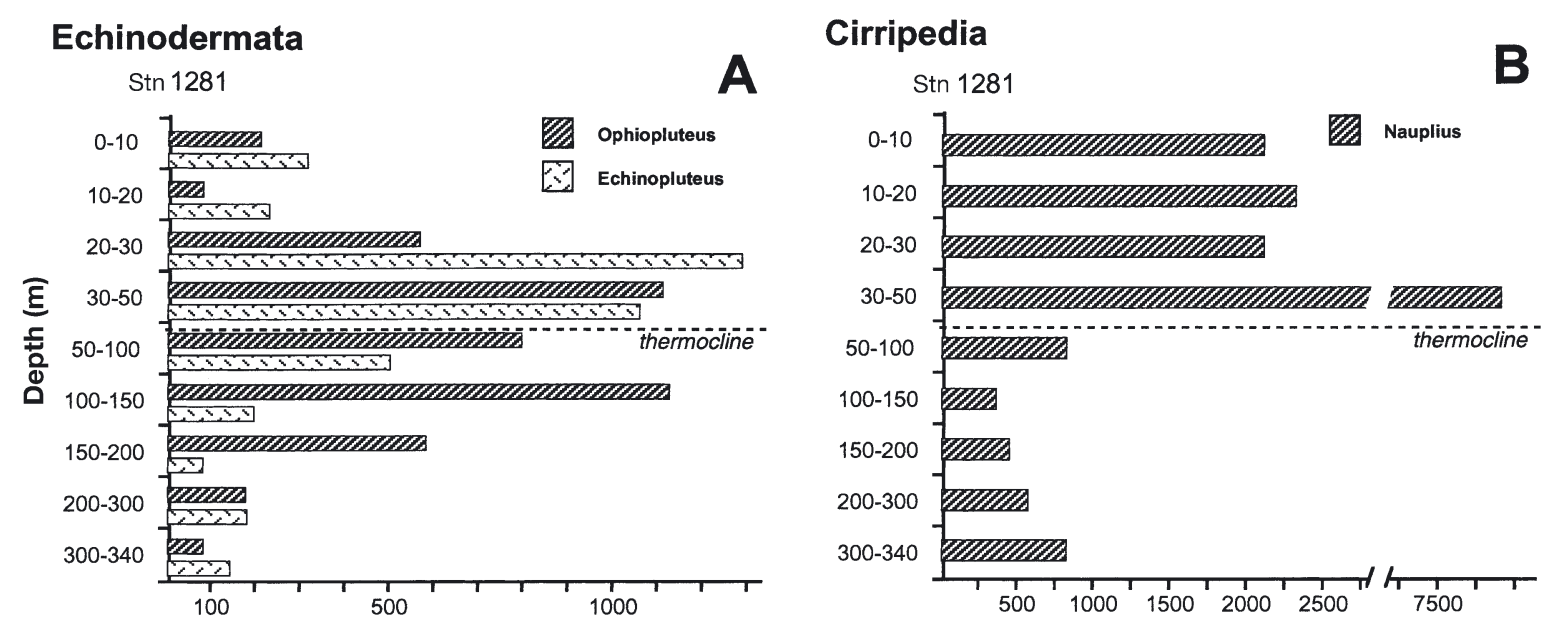

Abundance (ind. $\mathbf{m}^{-3}$ )

Fig. 6. Vertical distribution of echinoderm and cirripede larvae at Stn 1281. Dotted line = thermocline (at 70 to $80 \mathrm{~m}$ water depth, see Antezana et al. 1996) 
Decapod larvae presented a distinct distribution: thalassinid larvae (Notiax sp.) were found in conspicuous numbers demersally just above the seafloor (Fig. 7), especially in an advanced stage of larval development. The brachyuran Eurypodius latreillei and the caridean Austropandalus grayi were found in high abundances at Stn 1288, which presented a strong thermocline (Fig. 7, see also Antezana et al. 1996). All larval stages of these 2 species were found below the thermocline, but only in the case of $A$. grayi did their distribution extend to the seafloor (Fig. 7). A very similar pattern to E. latreillei was found for larvae of Munida spp. and Notiax spp. (Fig. 7) at Stn 1238. Data on temperature and salinity are not available from this station, and therefore it is not known whether a well-developed thermocline was present there.

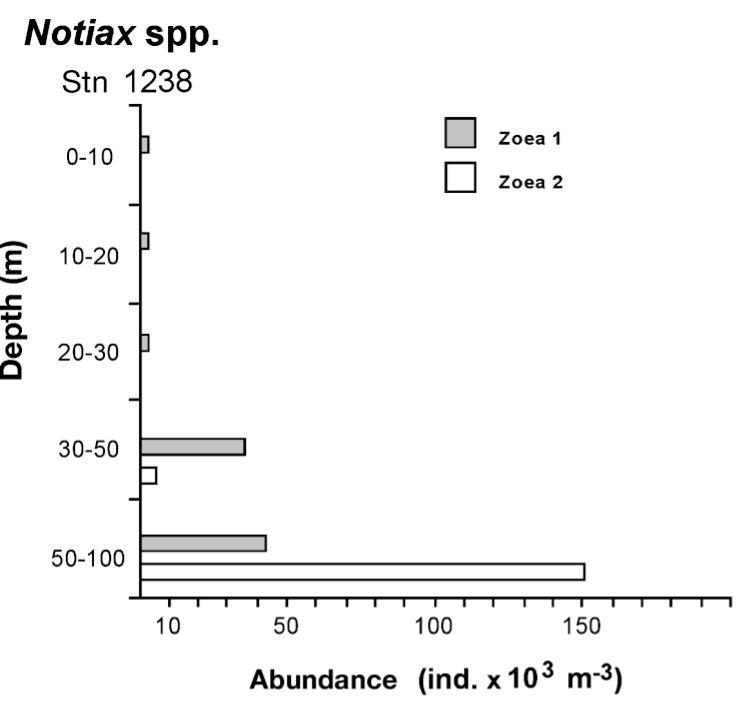

\section{Eurypodius latreillei}

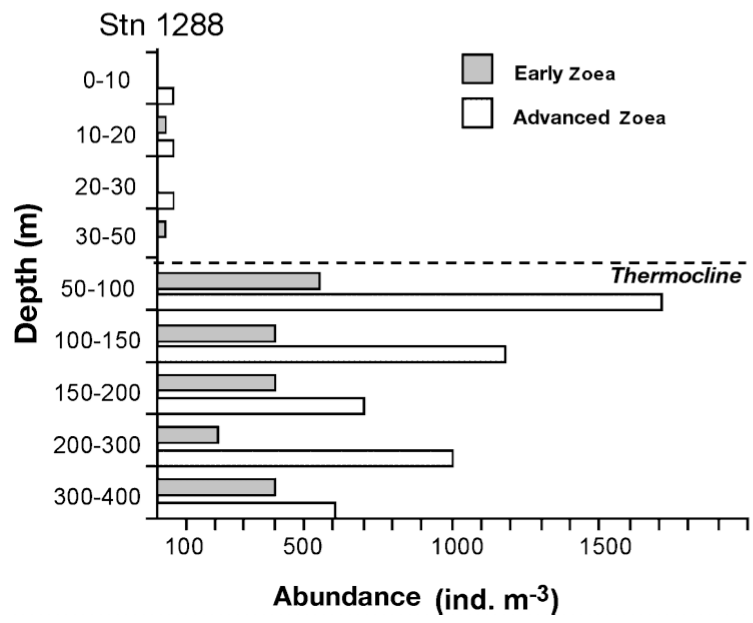

\section{Developmental modes in decapod larvae}

Three basic criteria of (1) morphogenesis, (2) mode of larval nutrition and (3) site of larval development were applied to characterise developmental modes in decapod larvae (cf. 'Materials and methods'). Independent of decapod infraorder, 3 basic larval developmental patterns were detected for the Magellan and south-western Atlantic decapod fauna (Table 2).

- Extended, planktotrophic development of planktonic larvae

- Abbreviated, planktotrophic development of planktonic larvae

- Abbreviated, lecithotrophic development of demersally living larvae.

\section{Munida spp.}

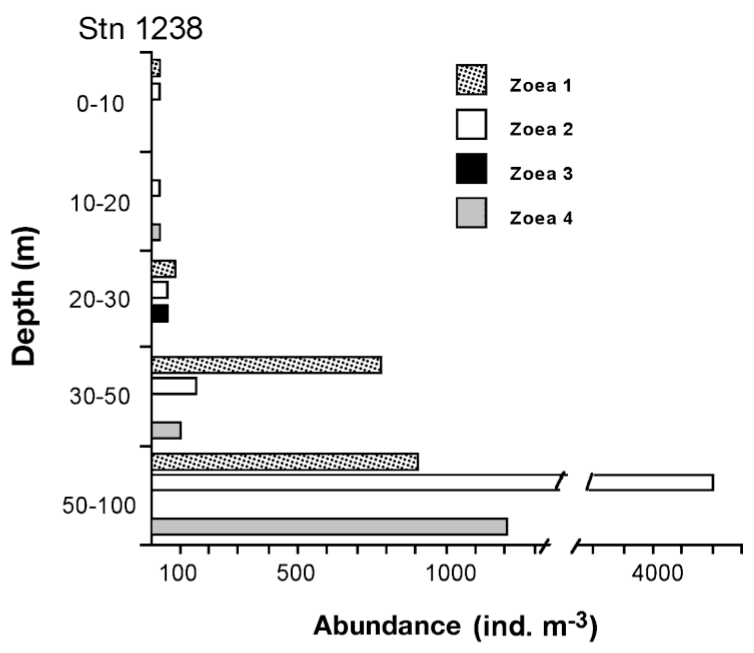

\section{Austropandalus grayi}

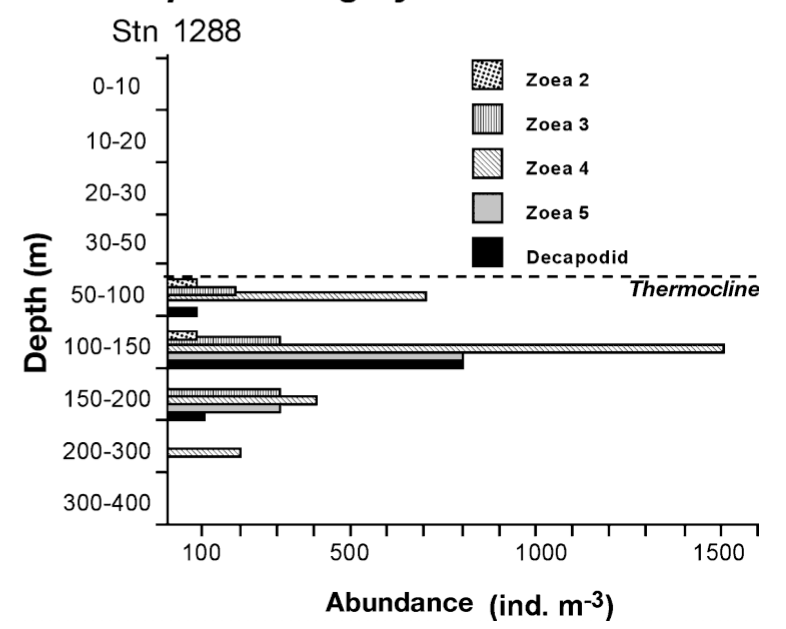

Fig. 7. Vertical distribution of selected decapod taxa from different sampling stations; Notiax sp. (Stn 1238), Munida spp. (Stn 1238), Eurypodius latreillei (Stn 1288), Austropandalus grayi (Stn 1288). Dotted line = thermocline (at 80 to $90 \mathrm{~m}$ water depth, see Antezana et al. 1996) 
Table 2. Selected decapod taxa from the Magellan region and the southwestern Atlantic Ocean with partially or completely known mode of larval development. Biogeographical information was obtained from Gorny (1999). (?) Uncertain information

\begin{tabular}{|c|c|c|c|c|c|c|c|c|}
\hline Species/Group & \multicolumn{3}{|c|}{$\begin{array}{c}\text { Duration } \\
\text { Extend- Abbre- } \\
\text { ed viated }\end{array}$} & \multicolumn{2}{|c|}{$\begin{array}{l}\text { Nutrition } \\
\text { Plankto- Lecitho- } \\
\text { trophic trophic }\end{array}$} & \multicolumn{2}{|c|}{$\begin{array}{c}\text { Habitat } \\
\text { Plank- } \\
\text { tonic }\end{array}$} & Source \\
\hline \multicolumn{9}{|l|}{ Caridea } \\
\hline Campylonotus vagans Bate, 1888 & & & $\mathrm{x}$ & $\mathrm{x}$ & & $\mathrm{x}$ & & 28,30 \\
\hline Campylonotus semistriatus Bate, 1888 & & & $\mathrm{x}$ & $\mathrm{x}$ & & $\mathrm{x}$ & & 28 \\
\hline Chorismus antarcticus (Pfeffer, 1887) & & & $\mathrm{x}$ & $\mathrm{x}$ & & $\mathrm{x}$ & & 6,19 \\
\hline Chorismus tuberculatus Bate, 1888 & & & $\mathrm{x}$ & $\mathrm{x}$ & & $\mathrm{x}$ & & 26 \\
\hline Betaeus truncatus Dana, 1852 & & ? & & $\mathrm{x}$ & & $\mathrm{x}$ & & 1,29 \\
\hline Eualus dozei (A. Milne Edwards, 1891) & & ? & & & & & & 1 \\
\hline Nauticaris magellanica A. Milne Edwards, 1891 & & & $\mathrm{x}$ & $\mathrm{x}$ & & $\mathrm{x}$ & & $1,27,33,34$ \\
\hline Austropandalus grayi (Cunningham, 1871) & & $\mathrm{x}$ & & $\mathrm{x}$ & & $\mathrm{x}$ & & 25 \\
\hline \multicolumn{9}{|l|}{ Palinura } \\
\hline Stereomastis (suhmi Bate, 1878, ?) & & & & & & & $\mathrm{x}$ & 21 \\
\hline \multicolumn{9}{|l|}{ Anomura } \\
\hline Munida subrugosa Henderson, 1847 & & $\mathrm{x}$ & & $\mathrm{x}$ & & $\mathrm{x}$ & & $17,22,32,35,36$ \\
\hline Munida gregaria (Fabricius, 1793) & & $\mathrm{x}$ & & $\mathrm{x}$ & & $\mathrm{x}$ & & $17,32,35,36$ \\
\hline Lithodes santolla (Molina, 1782) & & & $\mathrm{x}$ & & $\mathrm{x}$ & & $\mathrm{x}$ & $7,9,16,18,19$ \\
\hline Paralomis granulosa (Jaquinot, 1847) & & & $\mathrm{x}$ & & $\mathrm{x}$ & & $\mathrm{x}$ & $7,8,10,16,20$ \\
\hline Pagurus comptus White, 1847 & & $\mathrm{x}$ & & $\mathrm{x}$ & & $\mathrm{x}$ & & $17,23,24,31$ \\
\hline Pagurus forceps H. Milne Edwards, 1836 & & $\mathrm{x}$ & & $\mathrm{x}$ & & $\mathrm{x}$ & & $17,23,24,31$ \\
\hline Parapagurus (dimorphus Smith,?) & & & & & & & $\mathrm{x}$ & 3,21 \\
\hline \multicolumn{9}{|l|}{ Brachyura } \\
\hline Eurypodius latreillei Guérin, 1828 & & & $\mathrm{x}$ & $\mathrm{x}$ & & $\mathrm{x}$ & & $2,4,11,17$ \\
\hline Libidoclaea granaria (H. Mil. Edw. \& Lucas, 1842 & & $\mathrm{x}$ & & $\mathrm{x}$ & & $\mathrm{x}$ & & $4,12,17$ \\
\hline Halicarcinus planatus (Fabricius, 1775) & & $\mathrm{x}$ & & $\mathrm{x}$ & & $\mathrm{x}$ & & 5,17 \\
\hline Peltarion spinosulum (White, 1843) & & $\mathrm{x}$ & & $\mathrm{x}$ & & $\mathrm{x}$ & & 14,17 \\
\hline Pinnixia sp. & & $?$ & & $\mathrm{x}$ & & $\mathrm{x}$ & & 13,17 \\
\hline Cancer edwardsi Bell, 1835 & & $\mathrm{x}$ & & $\mathrm{x}$ & & $\mathrm{x}$ & & 15 \\
\hline \multicolumn{9}{|l|}{ Astacidea } \\
\hline Thymops birsteini (Zarenkov \& Semenov, 1972) & & & & & & & $?$ & 21 \\
\hline \multicolumn{9}{|l|}{ Thalassinidea } \\
\hline Notiax sp. (?) & & & & & & & $\mathrm{x}$ & 21 \\
\hline \multicolumn{9}{|l|}{ Sources } \\
\hline (1) Albornoz \& Wehrtmann (1997) & $(13)$ & ) Guti & ierrez-Ma & inez (1971) & & (25) $\mathrm{T}$ & Thatje \& B & 3acardit (2000a) \\
\hline (2) Bacardit (1985b) & (14) & ) Iorio & $(1983)$ & & & (26) $\mathrm{T}$ & Thatje \& B & 3acardit (2000b) \\
\hline (3) Bacardit (1985a) & (15) & ) Quin & ntana $(198$ & & & (27) $\mathrm{T}$ & Thatje \& B & 3acardit (2000c) \\
\hline (4) Bacardit \& Vera (1986) & (16) & Kattr & ner et al. & 003) & & (28) $\mathrm{T}$ & Thatje et a & al. (2001) \\
\hline (5) Boschi et al. (1969) & (17) & Lovr & ich $(1999$ & & & (29) $\mathrm{T}$ & Thatje \& B & 3acardit (2001) \\
\hline (6) Bruns (1992) & (18) & Lovr & ich et al. & 003) & & (30) $\mathrm{T}$ & Thatje \& L & _ovrich (2003) \\
\hline (7) Calcagno et al. (2003a) & (19) & $\mathrm{McL}$ & aughlin e & al. (2001) & & (31) $\mathrm{T}$ & Thatje \& L & _ovrich (unpubl.) \\
\hline (8) Calcagno et al. (2003b) & (20) & $\mathrm{McL}$ & aughlin e & al. (2003) & & $(32) \mathrm{V}$ & Vera \& Ba & cardit (1986) \\
\hline (9) Campodonico (1971) & (21) & ) Prese & ent study & & & (33) V & Wehrtman & in \& Albornoz (1998) \\
\hline (10) Campodonico \& Guzman (1972) & (22) & Robe & erts $(1973$ & & & $(34) \mathrm{V}$ & Wehrtman & n \& Kattner (1998) \\
\hline (11) Campodonico \& Guzman (1981) & (23) & Scelz & $\mathrm{zo} \& \mathrm{Bosc}$ & i (1969) & & $(35) \mathrm{V}$ & Williams $(1$ & 1973) \\
\hline (12) Fagetti (1969) & (24) & Scelz & zo (1976) & & & $(36) \mathrm{V}$ & Williams (1) & 1980) \\
\hline
\end{tabular}

Brachyuran crabs seem to follow a general pattern of extended larval development, whereas caridean shrimp genera (Chorismus, Campylonotus, Table 2), which also have Antarctic representatives, follow an abbreviated larval development. Complete endotrophy in abbreviated larval development has so far only been recorded in lithodid crabs from the study area (Table 2).

\section{DISCUSSION}

\section{Sampling method and identification of decapod larvae}

Among several key ecological problems in high latitude marine larval biology is the general lack of early life history studies in marine invertebrates (but see 
Pearse et al. 1991). This deficiency affects many aspects of ecological work and the development of ecological concepts, and only allows for broad generalisations as to larval developmental modes in the present study (Table 2). Sampling of meroplankton communities with a plankton net of $300 \mu \mathrm{m}$ mesh size underestimated the true amount of invertebrate larvae. This should have affected meroplankton composition in particular, and especially smaller larval types, such as molluscs and echinderms, should be underrepresented. This should reduce the real decapod larval dominance to some extent. However, invertebrate larvae tend to be larger in cold temperate and polar regions (Thorson 1936, Mileikowsky 1971, Pearse et al. 1991), and this holds especially true for decapod larvae (Thatje \& Bacardit 2000b,c, Thatje et al. 2001). The smallest decapod larvae known from the Beagle Channel is that of Betaeus truncatus (the Zoea I instar has an average total length of about $3.5 \mathrm{~mm}$, see Thatje \& Bacardit 2001), which was found in low abundance in our samples, and this species is generally known to occur in minor abundances within the benthic community (Pérez-Barros et al. in press).

All decapods which spend the greater part of their larval development in the plankton were considered planktotrophic, assuming that active feeding is necessary at least during part of the larval development, although development might be temporarily food independent, relying on high initial/maternal energy sources (for a review see Anger 2001). Since endotrophic larval development in benthic decapods tends to avoid pelagic phases (Anger et al. 2003, Lovrich et al. 2003) and complete lecithotrophic larval development is scarcely reported in marine carideans, we believe our generalisation in larval developmental modes to be a useful tool in describing decapod reproductive patterns. The definition of 'abbreviated' larval development in reptants is easy to apply, since most representatives (especially brachyuran crabs) usually develop through 4 to 6 zoeal stages and 1 megalopa stage (Williamson 1982, Anger 2001). A great variation in larval developmental pathways and larval instars has been described for caridean shrimps. We considered caridean larval developments as abbreviated when passing through 4 or less zoeal stages only, i.e. as in the genera Campylonotus (Thatje et al. in press) and Chorismus (Bruns 1992, Thatje \& Bacardit 2000b). However, it has to be considered that this is a rather arbitrary definition of abbreviated development in carideans, which is only based on the number of instars, but does not take larval developmental times into account. The larval development of Nauticaris magellanica was also considered abbreviated (Table 2), as it was found to be reduced with increasing latitude (5 to 6 zoeal stages found in the present study area compared with 9 to 11 stages in central southern Chile, Wehrtmann \& Albornoz 1998, Thatje \& Bacardit 2000c).

\section{Occurrence and distribution of invertebrate larvae}

The difference in faunal composition between deepand shallow-water stations (cf. Fig. 5) is due to the dominance of decapod crustaceans in the semienclosed hydrographic environment of the Beagle Channel, which is known for its richness in decapods (Gorny 1999, Pérez-Barros et al. unpubl.). Species richness in Subantarctic meroplankton is low and dominated in terms of abundance and diversity by decapod crustaceans with clear seasonal reproduction mainly taking place in spring (Lovrich 1999). It is not certain whether the high proportion of thalassinid larvae found in the Beagle Channel is due to the local distribution of the few species of this infraorder known from the area (see Thatje 2000, Thatje \& Gerdes 2000), or to a direct coupling with larval release at the Beagle Channel stations. However, thalassinid shrimps depend on muddy to sandy sediments, which are abundant in the Beagle Channel, but coarser and more heterogeneous sediments are known on the station transect northward to the Straits of Magellan (Fig. 1) (Brambati et al. 1991). Decapod larval development seems to take place mainly in the midwater masses below the thermocline (if developed), where plankton particles are enriched, and consequently food availability is high. However, further studies are needed to define whether larvae show a vertical migration tendency, which may affect this distribution pattern. Decapod species that develop through demersally occurring larvae only, which are mostly of abbreviated and food-independent development as in lithodid crabs (McLaughlin et al. 2001, Calcagno et al. 2003a, Kattner et al. 2003), are rarely found in plankton hauls (Lovrich 1999).

\section{The phylogenetic constraint of being tied to planktotrophic larval developments}

The reason why caridean shrimps are successful in Antarctic waters has been assigned to their ability to down-regulate high $\mathrm{Mg}^{2+}$ concentrations in the haemolymph (Frederich et al. 2001); a mechanism which functions insufficiently in reptants. Despite this physiological ability to maintain activity levels in the cold (which remains scarcely studied in larvae), carideans show a great flexibility in larval developmental pathways at lower latitudes. This flexibility increases with the number of larval instars, and enhances larval dis- 
persal and survival (Anger 2001). The requirements for exogenous energy from food allowing for developmental flexibility and extended modes of larval development should be high, as metabolic costs for additional moults as well as energy losses with cast exuviae imply a high degree of dependence on plankton productivity (Wehrtmann 1991, Anger 2001). Nevertheless, the flexibility in larval developmental pathways also allowed carideans to evolve energy saving strategies when low temperatures and limited food availability selected for abbreviated and partially endotrophic modes of larval development. This has been hypothesised as a latitudinal pattern in reproductive traits in carideans such as an increase, from the equator towards the poles, in egg size, in initial energy reserves of eggs and larvae, and in larval size, coinciding with a reduction in fecundity and in the age at first maturity (Arntz et al. 1992, Thatje et al. in press a,b). The need for such energy saving strategies under conditions of low temperatures and a seasonally limited primary production in high latitudes has suppressed the extent and flexibility of developmental pathways in caridean larvae. For instance, strongly abbreviated larval developments passing invariably through only 2 or 4 larval instars in the sub- and high Antarctic genera Campylonotus and Chorismus, respectively (Table 2) (Bruns 1992, Thatje \& Bacardit 2000b, Thatje et al. in press a), combined with high larval resistance to starvation, especially in the Zoea 1 instar (Thatje et al. in press $a, b)$, allow for an enhanced synchronisation with short and pulsed periods of primary production, and simultaneously reduce the degree of larval dependence on planktonic food sources (Clarke 1988, Anger et al. 2003). Similar early life history adaptations are known also from the Antarctic crangonid Notocrangon antarcticus (Bruns 1992). In the high Antarctic Weddell Sea, carideans are able to spawn only every second year (Arntz et al. 1992, Gorny et al. 1992, Gorny \& George 1997), suggesting a lack of sufficient energy supply to female reproduction, due to short periods of primary production during summer, which may be insufficient for the level of somatic growth allowing for an annual reproductive cycle (Clarke 1982). In polar environments, the mismatch between energy availability and high costs for female energy investment into large embryos might thus have selected against complete lecithotrophy in caridean larval development. On the other hand, complete endotrophic larval development of pelagic larvae is rare in marine caridean shrimps (although frequently recorded in shrimps from limnic systems, especially Palaemonidae, cf. Magalhães 1988, Odinetz Collart \& Magalhães 1994), which may indicate a phylogenetic constraint for the evolution of lecithotrophic developments in the sea. One known exception, which should be men- tioned here, is the Subarctic Sclerocrangon boreas, which has a direct and abbreviated (lecithotrophic) development of benthic larvae, including a high degree of parental care (Makarov 1968, Miglavs 1992).

In general, brachyuran crabs have an extended planktotrophic mode of larval development. Cases of an abbreviated development or flexibility in the number of instars have usually been observed under conditions of physiological stress (Anger 2001) and as special adaptations to breeding in land-locked limnic or terrestrial habitats (Montú et al. 1990, Anger \& Schuh 1992, Anger 2001). An abbreviated larval development in some endemic terrestrial grapsoid crabs from Jamaica, for instance, has been shown to be a recent evolutionary adaptation to semi-terrestrial or terrestrial life (Schubart et al. 1998), which evolved only about 4 million years ago (for a discussion see Anger 2001). Resistance of brachyuran larvae to starvation is generally low, and examples of larval exposure to low temperatures have indicated that the use of energy sources is hampered by metabolic disturbance below critical temperatures (Anger et al. 1981, Pörtner 2002). The inability of most reptant decapods to suppress the number of larval stages should therefore have selected against their occurrence in high latitudes when the Antarctic region began to become cooler (Clarke 1990). However, one family of anomuran crabs, the lithodid crabs, which in evolutionary terms evolved quite recently, developed complete endotrophic larval development of demersal larvae. They evolved from hermit crab ancestors (Cunningham et al. 1992, this phylogenetic relation is the subject of recent controversial discussion, see also McLaughlin \& Lemaitre 2000), and were recorded for the first time between 13 to 25 million years ago, when other much older brachyuran and anomuran taxa (hermit crabs evolved more than 150 million years ago, Cunningham et al. 1992 and references therein) were already extinct in high southern latitudes due to Antarctic cooling (Zinsmeister \& Feldmann 1984, Feldmann \& Tshudy 1989). Lithodid crabs from the Magellan region (Paralomis granulosa, Lithodes santolla) developed special adaptations in life history, such as prolonged brooding of egg masses and, most importantly, complete lecithotrophy in larval development, which allowed for adaptation to ecological and physiological constraints in high latitudes (Frederich et al. 2001, Anger et al. 2003, Lovrich et al. 2003, Thatje et al. 2003). This evolutionarily young taxon of anomuran crabs, which is represented by several species in high latitudes of both hemispheres and also appears to be a common deepsea representative (Anger et al. 2003 and references therein), is obviously about to release itself from the apparent phylogenetic constraints that have prevented reptants from conquering the polar marine realm as a 
life habitat (Macpherson 1988, Klages et al. 1995, Arana \& Retamal 2000). We suggest a similar recent evolutionary trait to be responsible for abbreviated larval developments in spider crabs (Majidae), which are already present in both the Subarctic (e.g. Hyas araneus, Dyer 1985) and the Subantarctic (Eurypodius latreillei). Eurypodius latreillei Guerin, which at present is the southernmost known spider crab in the southern hemisphere, was recently confirmed to occur in waters off South Georgia (Romero et al. 2003). The Majidae are suggested as further possible recolonisers of the Polar marine realm.

Acknowledgements. We would like to thank the crew of the German RV 'Victor Hensen' for assistance at sea. Tanja Joschko and Mario Hubo helped in separating the meroplankton fraction. Claudio Richter (ZMT, Bremen) kindly provided the plankton samples. The authors would like to thank Klaus Anger and Gustavo Lovrich as well as Ingo Wehrtmann and 3 anonymous reviewers for critically commenting on the manuscript. Thanks are due to Ruth Alheit for her revision of the English.

\section{LITERATURE CITED}

Albornoz L, Wehrtmann IS (1997) Descripción y clave de los primeros estadíos larvales de camarones carídeos (Decapoda: Hippolytidae, Alpheidae, Rhynchocinetidae) de aguas costeras de Chile. Invest Mar Univ Catol Valparaíso 25:121-133

Anger K (2001) The biology of decapod crustacean larvae. Crustacean issues, Vol 14. A.A. Balkema, Lisse

Anger K, Schuh M (1992) Bioenergetics of abbreviated larval development in the bromelid crab, Metopaulias depressus (Decapoda: Grapsidae). Comp Biochem Physiol A 103: $507-518$

Anger K, Dawirs RR, Anger V, Goy JW, Costlow JD (1981) Starvation resistance in first stage zoeae of brachyuran crabs in relation to temperature. J Crustac Biol 1:518-525

Anger K, Thatje S, Lovrich GA, Calcagno JA (2003) Larval and early juvenile development of Paralomis granulosa reared at different temperatures: tolerance of cold and food limitation in a lithodid crab from high latitudes. Mar Ecol Prog Ser 253:243-251

Antezana T, Hamamé M, Eissler Y, Jara S (1996) Hydrography in Chilean fjords: Strait of Magellan to Beagle Channel (legs 1 and 2). In: Arntz W, Gorny M (eds) Cruise report of the Joint Chilean-German-Italian Magellan 'Victor Hensen' Campaign in 1994. Ber Polarforsch 190:16-18

Arana PM, Retamal MA (2000) Nueva distribución de Paralomis birsteini Macpherson 1988 en aguas antártidas (Anomura, Lithodidae, Lithodinae). Invest Mar Univ Catol Valparaíso 27:101-110

Arntz WE, Gili JM (2001) A case for tolerance in marine ecology: Let us not put out the baby with the bathwater. Sci Mar 65(Suppl 2):283-299

Arntz W, Gorny M (1996) Cruise report of the Joint ChileanGerman-Italian Magellan 'Victor Hensen' Campaign in 1994. Ber Polarforsch 190:1-113

Arntz WE, Brey T, Gerdes D, Gorny M, Gutt J, Hain S, Klages M (1992) Patterns of life history and population dynamics of benthic invertebrates under the high Antarctic conditions of the Weddell Sea. In: Colombo G, Ferrari I, Ceccherelli VU, Rossi R (eds) Marine eutrophication and population dynamics. Proc 25th Europ Mar Biol Symp. Olsen \& Olsen, Fredensborg, p 221-230

Bacardit R (1985a) Larvas de Crustacea Deacpoda del Atlantico sudoccidental. I. Primer estadio larval del genero Parapagurus Smith (Anomura, Parapaguridae). Physis (Buenos Aires) Secc A 43(105):73-77

Bacardit R (1985b) Larvas de crustacea Decapoda del Atlantico sudoccidental. II. Morfología de las larvas y postlarvas de Eurypodius latreillei Guerin (Brachyura, Majidae), provenientes de muestras de plancton del Mar Argentino. Physis (Buenos Aires) Secc A 43(105):79-89

Bacardit R, Vera V (1986) Larvas de Crustacea Decapoda del Atlantico sudoccidental. III. Distribución y abundancia de larvas y postlarvas de Eurypodius latreillei Guerin y Lipidoclaea granaria Milne-Edwards y Lucas (Brachyura, Majidae) en el Mar Argentino. Physis (Buenos Aires) Secc A 44(106):9-20

Boschi EE, Scelzo MA, Goldstein B (1969) Dessarrollo larval del cangrejo Halicarcinus planatus (Fabricius) (Crustacea, Decapoda, Hymenosomidae), en el laboratorio, con observaciones sobre la distribución de la especie. Bull Mar Sci 19(1):225-242

Brambati A, Fontolan G, Simeoni U (1991) Recent sediments and sedimentological processes in the Strait of Magellan. Boll Oceanol Teor Applic 9(2-3):217-259

Bruns T (1992) Experimentelle Untersuchungen zur Larvalentwicklung antarktischer Garnelen (Decapoda, Natantia). Diplomarbeit, Universität Osnabrück, (unpublished MSc thesis)

Calcagno JA, Lovrich GA, Anger K, Thatje S, Kaffenberger A (2003a) Larval development in the Subantarctic king crabs Lithodes santolla (Molina) and Paralomis granulosa (Jaquinot) reared in the laboratory. Helgol Mar Res 57: $110-113$

Calcagno JA, Thatje S, Anger K, Lovrich GA, Kaffenberger A (2003b) Changes in biomass and chemical composition during lecithotrophic larval development of the southern stone crab, Paralomis granulosa. Mar Ecol Prog Ser 257: 189-196

Campodonico I (1971) Desarrollo larval de la centolla Lithodes antarctica Jacquinot en condiciones de laboratorio (Crustacea Decapoda, Anomura: Lithodidae). An Inst Patagonia Ser Cienc Nat 2:181-190

Campodónico IG, Guzman LM (1972) Desarrollo larval de Eurypodius latreillei Guerin en condiciones de laboratorio. An Inst Patagonia Ser Cienc Nat 3(1/2):233-247

Campodónico I, Guzman L (1981) Larval development of Paralomis granulosa (Jaquinot) under laboratory conditions (Decapoda, Anomura, Lithodidae). Crustaceana 40: $278-285$

Clarke A (1982) Lipid synthesis and reproduction in polar shrimps. Mar Ecol Prog Ser 9:81-90

Clarke A (1988) Seasonality in the Antarctic marine environment. Comp Biochem Physiol B 90:461-473

Clarke A (1990) Temperature and evolution: Southern Ocean cooling and the Antarctic marine fauna. In: Kerry KR, Hempel G (eds) Antarctic ecosystems. Ecological change and conservation. Springer Verlag, Berlin, p 9-22

Clarke KR, Gorley RN (2001) Primer V.5: user manual/ tutorial. Primer-E, Plymouth

Cunningham CW, Blackstone NW, Buss LW (1992) Evolution of king crabs from hermit crab ancestors. Nature 355: 539-542

Defren-Jansen K, Schnack-Schiel SB, Richter C (1999) Meso- 
zooplankton communities in the Magellan region. Sci Mar 63(Suppl 1):43-50

Dyers MF (1985) The distribution of Hyas araneus (L.) and Hyas coarctatus Leach (Crustacea: Decapoda: Brachyura) in the North Sea and the Svalbard region. J Mar Biol Assoc UK 65:195-201

Fagetti E (1969) The larval development of the spider crab Libidoclaea granaria H. Milne Edwards \& Lucas under laboratory conditions (Decapoda Brachyura; Majidae, Pisinae). Crustaceana 17:131-140

Feldmann RM, Tshudy DM (1989) Evolutionary pattern in macruros decapod crustaceans from Cretaceous to Early Cenozoic rocks of the James Ross Island region, Antarctica. In: Crame JA (ed) Origins and evolution of the Antarctic biota, Vol 47. Geological Society, London, p 183-195

Frederich M, Sartoris FJ, Pörtner HO (2001) Distribution patterns of decapod crustaceans in polar areas: a result of Magnesium regulation? Polar Biol 24:719-723

Gorny M (1999) On the biogeography and ecology of the Southern Ocean decapod fauna. Sci Mar 63(Suppl 1): 367-382

Gorny M, George MR (1997) Oocyte development and gonad production of Nematocarcinus lanceopes (Decapoda: Caridea) in the eastern Weddell Sea, Antarctica. Polar Biol 17:191-198

Gorny M, Arntz WE, Clarke A, Gore DJ (1992) Reproductive biology of caridean decapods from the Weddell Sea. Polar Biol 12:111-120

Gutierrez-Martinez J (1971) Notas biológicas sobre Pinnaxodes chilensis (M. Edwards) y descripción de su primera Zoea (Crustacea, Decapoda, Anomura). Mus Nac Hist Nat Mens (Santiago) 176:3-10

Iorio I (1983) Estadios larvales del cangrejo Peltarion spinosulum (White) (Crustacea, Decapoda, Brachyura, Atelecyclidae). Physis (Buenos Aires) Secc A 41(101):143-156

Kattner G, Graeve M, Calcagno JA, Lovrich GA, Thatje S, Anger K (2003) Lipid, fatty acid and protein utilization during lecithotrophic larval development of Lithodes santolla (Molina) and Paralomis granulosa (Jacquinot). J Exp Mar Biol Ecol 292:61-74

Klages M, Gutt J, Starmans A, Bruns T (1995) Stone crabs close to the Antarctic continent: Lithodes murrayi Henderson, 1888 (Crustacea; Decapoda; Anomura) off Peter I Island (68 $\left.51^{\prime} \mathrm{S}, 90^{\circ} 51^{\prime} \mathrm{W}\right)$. Polar Biol 15:73-75

Lovrich GA (1999) Seasonality of larvae of Brachyura and Anomura (Crustacea Decapoda) in the Beagle Channel, Argentina. Sci Mar 63(Suppl 1):347-354

Lovrich GA, Thatje S, Calcagno JA, Anger K, Kaffenberger A (2003) Changes in biomass and chemical composition during lecithotrophic larval development of the Southern king crab, Lithodes santolla (Molina). J Exp Mar Biol Ecol 288:65-79

Macpherson E (1988) Three new species of Paralomis (Crustacea, Decapoda, Anomura) from the Pacific and Antarctic oceans. Zool Scr 17:69-75

Magalhães C (1988) The larval development of palaemonid shrimps from the Amazon region reared in the laboratory. II. Extremely abbreviated larval development in Euryrhynchus Miers, 1877 (Decapoda, Euryrhynchinae). Crustaceana 55:39-52

Makarov RR (1968) On the larval development of the genus Sclerocrangon GO Sars (Caridea, Crangonidae). Crustaceana 2(Suppl):27-37

McLaughlin PA, Lemaitre R (2000) Aspects of evolution in the anomuran superfamily Paguroidea: one larval perspective. Invertebr Reprod Dev 38(3):159-169

McLaughlin PA, Anger K, Kaffenberger A, Lovrich GA (2001)
Megalopal and early juvenile development in Lithodes santolla (Molina, 1782) (Decapoda: Anomura; Paguroidea: Lithodidae), with notes on zoeal variations. Invertebr Reprod Dev 40:53-67

McLaughlin PA, Anger K, Kaffenberger A, Lovrich GA (2003) Larval and early juvenile development in Paralomis granulosa (Jacquinot) (Decapoda: Anomura: Paguroidea: Lithodidae), with emphasis on abdominal changes in megalopal and crab stages. J Nat Hist 37:1433-1452

Miglavs IJ (1992) Sclerocrangon boreas, the sculptured shrimp: a new species for mariculture. Some primary results of cultivation. 1st Eur Crustac Conf Paris (31 Aug to 5 Sep 1992) Abstracts. Mus Nat Hist Nat, Paris, p 99

Mileikovsky SA (1971) Types of larval development in marine bottom invertebrates, their distribution and ecological significance: a re-evaluation. Mar Biol 10:193-213

Montú M, Anger K, Bakker C (1990) Variability in the larval development of Metsasarma rubripes (Decapoda, Grapsidae) reared in the laboratory. Neritica 5(1):113-128

Odinetz Collart O, Magalhães C (1994) Ecological constraints and life history strategies of palaemonid prawns in Amazonia. Verh Internat Verein Limnol 25:2460-2467

Pearse JS, McClintock JB, Bosch I (1991) Reproduction of Antarctic benthic marine invertebrates: tempos, modes, and timing. Am Zool 31:65-80

Pérez-Barros P, Tapella F, Romero MC, Calcagno JA, Lovrich GA (in press) Benthic decapod crustaceans associated to captures of Munida spp. (Decapoda: Anomura) in the Beagle Channel, Argentina. Sci Mar

Pörtner HO (2002) Climate variations and the physiological basis of temperature dependent biogeography: systemic to molecular hierarchy of thermal tolerance in animals. Comp Biochem Physiol A 132:739-761

Quintana R (1983) Larval development of the edible crab, Cancer edwardsi Bell, 1835, under laboratory condition (Decapoda, Brachyura). Rep USA Mar Biol Inst Kochi Univ 5:1-19

Roberts PE (1973) Larvae of Munida subrugosa (White 1847), from Perseverance Harbour, Campbell Island. J R Soc NZ 3(3):393-408

Romero MC, Tapella F, Lovrich GA, Thatje S (2003) Reproductive modes and distribution of benthic decapod crustaceans along the Scotia Arc. Ber Polarforsch (in press)

Scelzo MA (1976) Larvas de los crustaceos decapodos anomuros, identificadas en las aguas marinas Argentinas. Physis (Buenos Aires) Secc A 35(90):37-45

Scelzo MA, Boschi EE (1969) Desarrollo larval del cangrejo ermitaño Pagurus exilis (Benedict) en laboratorio (Crustacea, Anomura, Paguridae). Physis (Buenos Aires) Secc A 29(78):165-184

Schubart CD, Diesel R, Hedges SB (1998) Rapid evolution to terrestrial life in Jamaican crabs. Nature 393:363-365

Thatje S (2000) Notiax santarita, a new species of the Callianassidae (Decapoda, Thalassinidea) from the Beagle Channel, southernmost America. Crustaceana 73(3):289-299

Thatje S, Bacardit R (2000a) Larval development of Austropandalus grayi (Cunningham, 1871) (Decapoda: Caridea: Pandalidae) from the southwestern Atlantic Ocean. Crustaceana 73(5):609-628

Thatje S, Bacardit R (2000b) Larval stages of Chorismus tuberculatus (Decapoda: Caridea: Hippolytidae) from the southwestern Atlantic Ocean. J Mar Biol Assoc UK 80:465-471

Thatje S, Bacardit R (2000c) Morphological variability in larval stages of Nauticaris magellanica (A. Milne Edwards, 1891) (Decapoda: Caridea: Hippolytidae) from South American waters. Bull Mar Sci 66(2):375-398

Thatje S, Bacardit R (2001) Two zoeal stages of Betaeus trun- 
catus (Dana, 1852) (Decapoda: Caridea: Alpheidae) from Argentine coastal waters. An Inst Patagonia Ser Cienc Nat 29:95-104

Thatje S, Gerdes D (2000) Upogebia australis, a new species of the Upogebiidae (Crustacea, Decapoda, Thalassinidea) from the Beagle Channel (Magellan Region). Mitt Mus Naturkunde Berlin, Zool Reih 76(2):231-236

Thatje S, Lovrich GA (2003) Decapodid and early juvenile development in the protandrous shrimp Campylonotus vagans Bate, 1888 (Crustacea: Decapoda), with notes on larval morphology. J Mar Biol Assoc UK 83(1):103-109

Thatje S, Bacardit R, Romero MC, Tapella F, Lovrich GA (2001) Description and key to the zoeal stages of the Campylonotidae (Decapoda, Caridea) from the Magellan Region. J Crustac Biol 21(2):492-505

Thatje S, Calcagno JA, Lovrich GA, Sartoris FJ, Anger K (2003) Extended hatching periods in the Subantarctic lithodid crabs Lithodes santolla and Paralomis granulosa (Crustacea: Decapoda). Helgol Mar Res 57:110-113

Thatje S, Lovrich GA, Anger K (in press a) Egg production, hatching rates, and abbreviated larval development of Campylonotus vagans Bate, 1888 (Crustacea: Decapoda: Caridea) in subantarctic waters. J Exp Mar Biol Ecol

Thatje S, Lovrich GA, Torres G, Hagen W, Anger K (in press b) Changes in biomass, lipid, fatty acid and elemental composition during the abbreviated larval development of the subantarctic shrimp Campylonotus vagans Bate, 1888. J Exp Mar Biol Ecol

Thorson G (1936) The larval development, growth and metabolism of Arctic marine bottom invertebrates

Editorial responsibility: Otto Kinne (Editor),

Oldendorf/Luhe, Germany compared with those of other seas. Medd Gronl 100:1-155 Thorson G (1950) Reproductive and larval ecology of marine bottom invertebrates. Biol Rev 25:1-45

Vera V, Bacardit R (1986) Larvas de Crustacea Decapoda del Atlantico sudoccidental. IV. Nuevas larvas del genero Munida Leach. (Anomura, Galatheidae). Physis (Buenos Aires) Secc A 44(107):59-66

Wehrtmann IS (1991) How important are starvation periods in early larval development for survival of Crangon septemspinosa larvae? Mar Ecol Prog Ser 73:183-190

Wehrtmann IS, Albornoz L (1998) Larval development of Nauticaris magellanica (A. Milne Edwards, 1891) (Decapoda: Caridea: Hippolytidae), reared under laboratory conditions. Bull Mar Sci 62(1):45-72

Wehrtmann IS, Kattner G (1998) Changes in volume, biomass, and fatty acids of developing eggs in Nauticaris magellanica (Decapoda: Caridea): a latitudinal comparison. J Crustac Biol 18(3):413-422

Williams BG (1973) The effect of the environment on the morphology of Munida gregaria (Fabricius) (Decapoda, Anomura). Crustaceana 24:197-210

Williams BG (1980) The pelagic and benthic phases of postmetamorphic Munida gregaria (Fabricius) (Decapoda, Anomura). J Exp Mar Biol Ecol 42:125-141

Williamson DI (1982) Larval morphology and diversity. In: Abele LG (ed) The biology of Crustacea, Vol 2. Embryology, morphology, and genetics. Academic Press, New York, p 43-110

Zinsmeister WJ, Feldmann RM (1984) Cenozoic high latitude heterochroneity of southern hemisphere marine faunas. Science 224:281-283

Submitted: April 23, 2003; Accepted: July 15, 2003

Proofs received from author(s): September 4, 2003 